\title{
Approximation of math model of the combined cutting soil's critical depth with influence of working speed
}

\author{
Sviatoslav Kravets ${ }^{1}$, Roman Zoria ${ }^{2}$ \\ National University Of Water And Environmental Engineering \\ 11, Soborna Str., Rivne, Ukraine, 33028 \\ 's.v.kravets@nuwm.edu.ua, orcid.org/0000-0003-4063-1942 \\ '2romkazorka@gmail.com, orcid.org/0000-0002-3024-7173
}

The manuscript was received on 30.03.2017 and was accepted after revision for publication on 15.10.2017

DOI: $10.26884 / 1707.1302$

\begin{abstract}
The purpose is approximation of mathematical model of processes of cutting and loosening of the soil for the receipt of analytical dependence of determination of critical depth of loosening taking into account the working speed at the combined tiered destruction of soil. An approximation based on regression analysis used in the processing of data derived from experiments with a number of parallel observations in the experiment. Built graph of the dependency between relative critical depth, working speed of the working body and angle cutting soil. Identify the value of critical depth loosening for five types of soil and full range of working speeds, depending on the physical and mechanical properties of the soil.

Keywords: angle cutting, depth loosening, operating speed, critical depth, free cutting, blocked cutting, combined cutting
\end{abstract}

\section{INTRODUCTION}

To eliminate the overcritical zone soil loosening and reduce the energy workflow [1 $-3,22]$, need to know the critical depth of cutting depending on cut conditions (upper lower tier) and initial data for soil and speed of the working body [4 - 7]. Process of tiered combined cutting soil and mathematical model of determination the critical depth of loosening were examined and described in previous articles $[8,9,20]$.

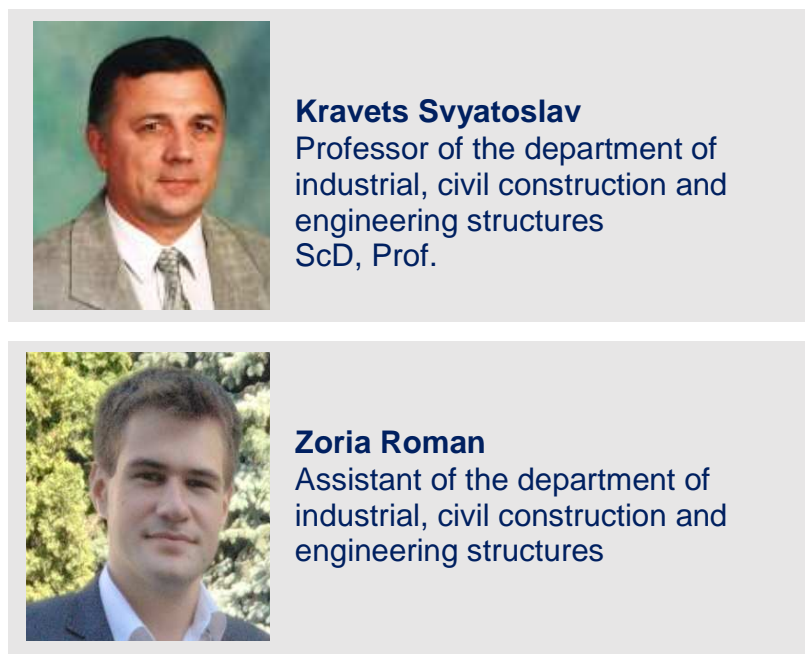

To study the combined critical depth considering working speed was considered the destruction of soil unpin based on scheme (Fig.1), at the same time as the initial conditions were accepted the following assumptions:

1) soil - homogeneous isotropic medium characterized clutch, external and internal friction, density and moisture content;

2) the element of chip is viewing as a solid body in the form of a triangular prism with two symmetrical conical sectors on each sides; 
3) the normal law of pressure distribution on the frontal plane of the working body in the chipping area is taken linear for the depth;

4) the critical depth is constant apart of work of working body in landing mode or in steady mode.

Because of these researches was obtained mathematical model of the critical depth of cut in the combined tiered destruction of soil considering the working speed:

$$
h_{\kappa p . \kappa}=\frac{-B-\sqrt{B^{2}-4 A C}}{2 A} \text {, }
$$

where $v, \alpha_{\mathrm{p}}, \psi$ - speed, cutting angle shear soil and cleaving soil angle; (look Fig.1); $v_{\text {кр }}$ - critical cutting speed at which changes the nature of the destruction of soil [9]; $q_{1}-$ maximum soil pressure on the knife's surface in the upper tier by free-cutting process; $q_{\mathrm{\kappa р}}$ - critical value of pressure; $b_{\mathrm{K}}$ - width of the knife; $\gamma_{г р}, \mathrm{c}-$ specific gravity and friction coefficient of soil; $g$ - acceleration of gravity; $\varphi$ - angle of soil external friction; $\varphi_{0}-$ angle of soil internal friction; $k_{\text {пер }}-$ the ratio of the depth zone of guaranteed chipping soil $\left(k_{\text {пер }}=0,9 \ldots 0,95\right) ; q_{0}-$ the minimum value of pressure, acting on the surface; $h_{\mathrm{B}}, h_{\text {бл2 }}-$ depth of soil operation in a free and blocked cutting respectively; $\gamma, \gamma_{\mathrm{K}}-$ collapse zones angles on combined cutting the soil in upper and lower tiers respectively [21]; $\rho, \delta, \lambda-$ angles formed by lateral chipping plane with the vertical plane.

$$
\begin{aligned}
& A=\left(\operatorname{ctg} \psi+\operatorname{ctg} \alpha_{\mathrm{p}}\right) c\left(\frac{\rho}{\sin \psi}+\frac{\cos \delta}{\cos \lambda}\right)-\frac{\sin \left(\alpha_{\mathrm{p}}+\varphi+\varphi_{0}+\psi\right)}{\cos \varphi \cos \varphi_{0} \sin \alpha_{\mathrm{p}}} b_{\mathrm{\kappa}}\left(1+\frac{v}{v_{\text {кр }}}\right) \times \\
& \times \frac{\gamma_{\text {гp }}}{\mathrm{g}} \frac{\sin ^{2} \alpha_{\mathrm{p}} \cos \psi \operatorname{os} \psi \varphi}{\sin \left(\alpha_{\mathrm{p}}+\psi\right) \sin \left(\alpha_{\mathrm{p}}+\varphi\right)} v^{2} \frac{\operatorname{ctg} \gamma}{2 b_{\mathrm{K}}}
\end{aligned}
$$

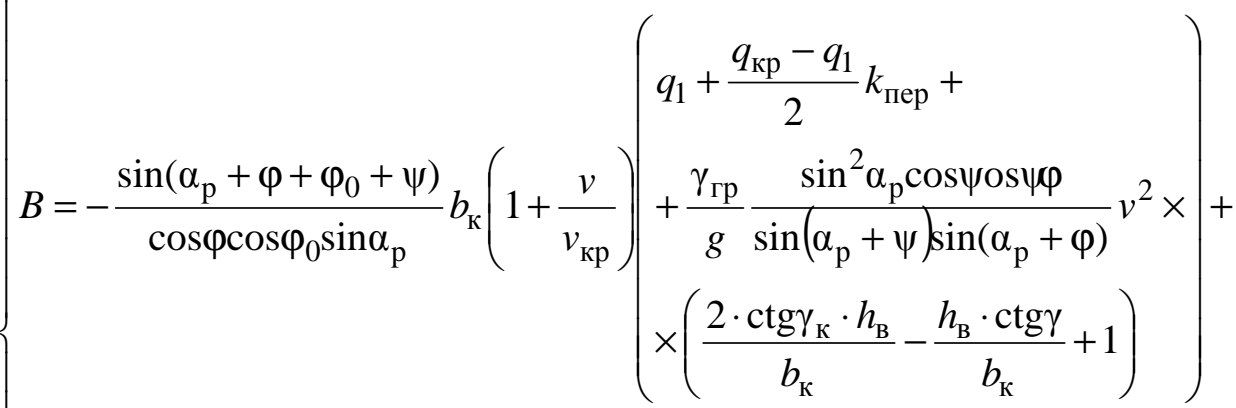

$$
\begin{aligned}
& +\left(2 h_{\mathrm{B}} \operatorname{ctg} \gamma_{\mathrm{K}}+b_{\mathrm{K}}\right) \frac{\mathrm{c}}{\sin \psi}-2 \mathrm{c}\left(\operatorname{ctg} \psi+\operatorname{ctg} \alpha_{\mathrm{p}}\right)\left(\frac{\rho}{\sin \psi}+\frac{\cos \delta}{\cos \lambda}\right) h_{\mathrm{B}}
\end{aligned}
$$

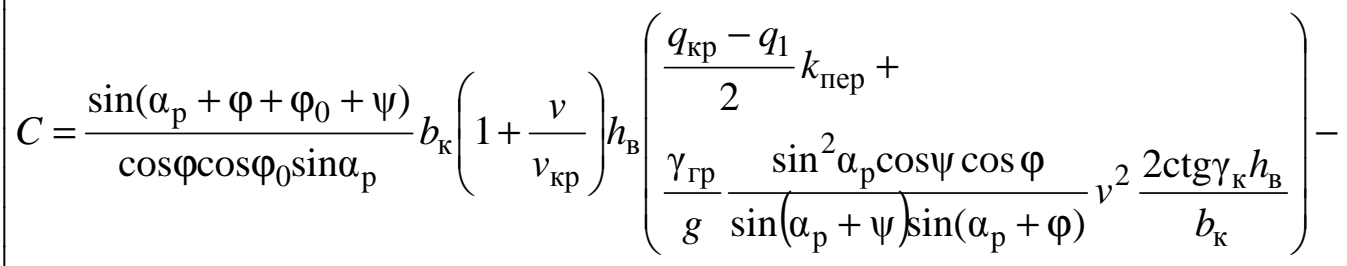

$$
\begin{aligned}
& -\left(2 h_{\mathrm{B}}^{2} \operatorname{ctg} \gamma_{\mathrm{K}}+\frac{h_{\mathrm{B}}^{2} \operatorname{ctg} \gamma}{2}\right) \frac{\mathrm{c}}{\sin \psi}+\mathrm{c}\left(\operatorname{ctg} \psi+\operatorname{ctg} \alpha_{\mathrm{p}}\right)\left(\frac{\rho}{\sin \psi}+\frac{\cos \delta}{\cos \lambda}\right) h_{\mathrm{B}}^{2} \text {. }
\end{aligned}
$$




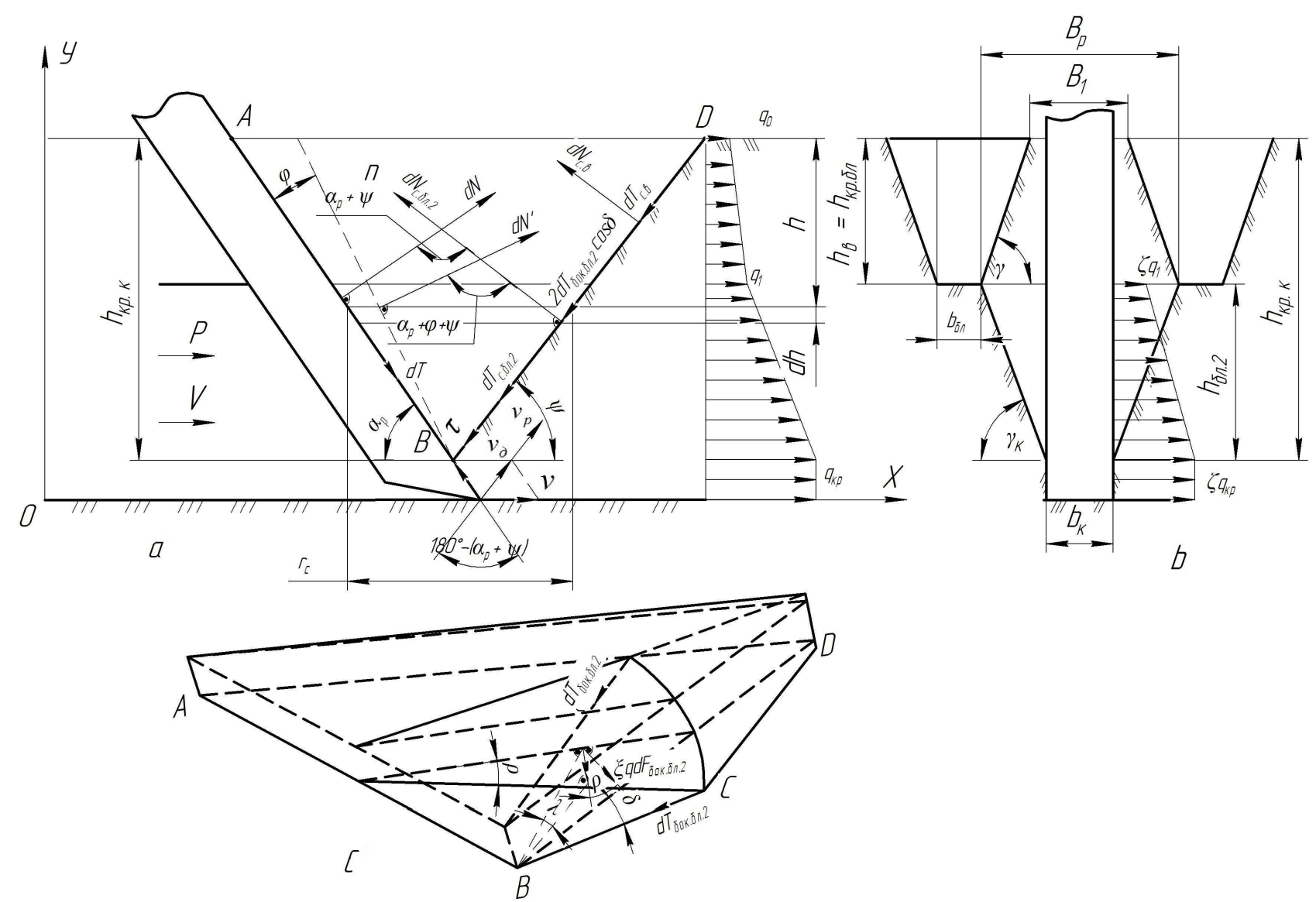

Fig.1. The scheme of interaction of a knife with soil environment about combined cutting soil: $a$ - in the longitudinal plane; $b$ - in the transverse plane; $c$ - the form of chip`s element in the knife hollowing process

Calculated value of the relative depth of cleavage in view of working speed listed in the Table 1.

As the mathematical model is quite cumbersome and not easy to compute and further research is necessary to make an approximation of the model. For realization of approximating will use the regression multivariate analysis [11 - 13].

To determine the $b$ - coefficient used regression analysis based on the method of least squares $[18,19]$.

Will write the equation of theoretical mathematical model of the critical depth of cut considering the speed in general view:

$$
\begin{aligned}
& y=b_{0}+b_{1} x_{1}+b_{2} x_{2}+b_{3} x_{3}+ \\
& +b_{1,2} x_{1} x_{2}+b_{1,3} x_{1} x_{3}+b_{2,3} x_{2} x_{3}+ \\
& +b_{1,2,3} x_{1} x_{2} x_{3}
\end{aligned}
$$

where $b_{0}$ - free member; $b_{1}, b_{2}, b_{3}, b_{1,2}, b_{1,3}, b_{2,3} b_{1,2,3}$ - factors that take into account linear impact on the interaction feedback factors of the first, second and third orders [10].

Draw the transfer of levels` factors natural values in the code dimensionless quantities in order to further build of standard matrix (Table 2):

$$
x_{k}=\frac{X_{k}-X_{k_{0}}}{\Delta X_{k}} \text {, }
$$

where $x_{k}-$ coded values of $k$-factor; $X_{k}-$ natural current value of $k$-factor; $X_{k_{0}}-$ initial (zero) level $X_{k_{0}}=\frac{X_{\max }+X_{\min }}{2}$ - factor; $\Delta X_{k}-$ the interval of variation of $k$-factor. the interval of variation of $k$-factor [14 - 16]. 
After the coding level factors take values: "1" - the upper level; "-1" - lower level; "0" - zero level. As zero level, take the center of spacing, which conducted the study (Table 3 ).

Table 1. Value of relative critical depth

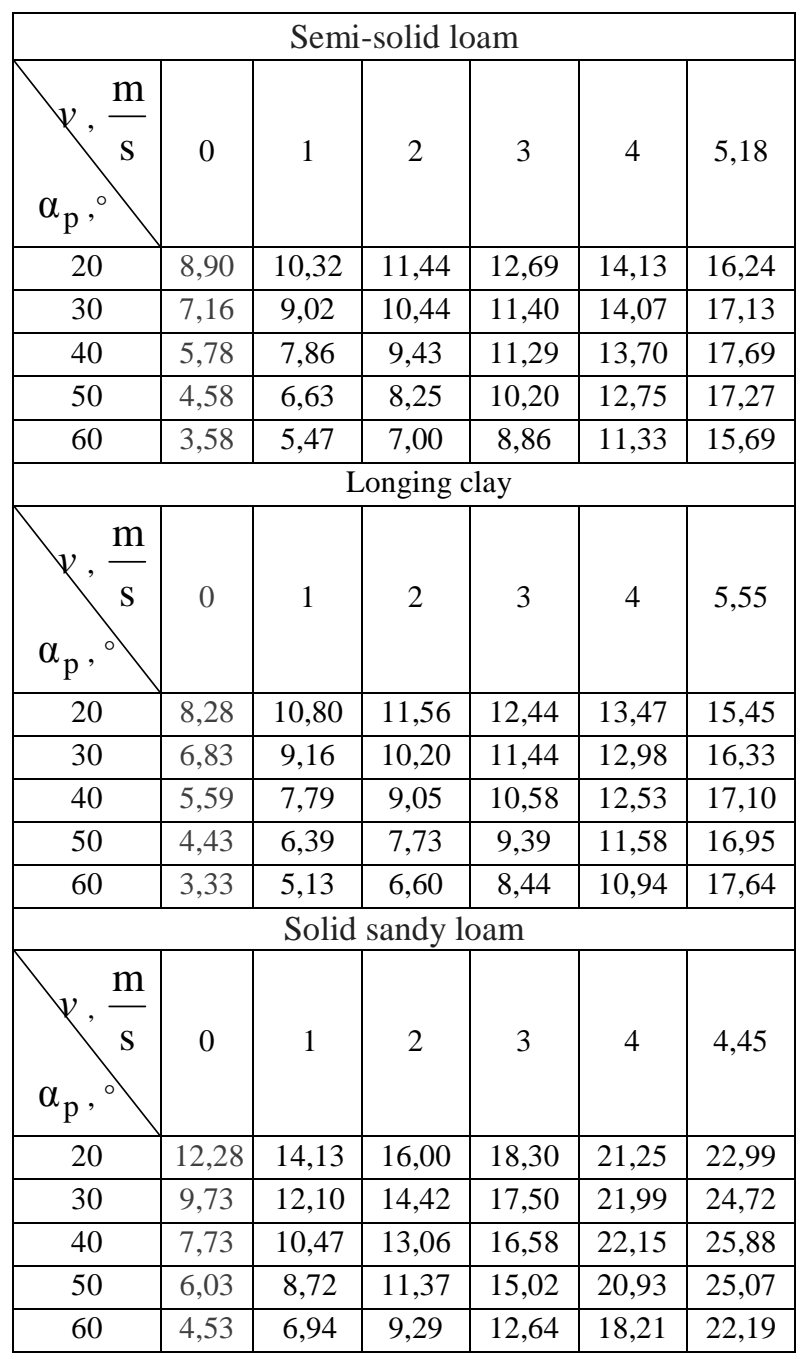

Regression coefficients calculated by the formula:

$$
\begin{gathered}
b_{0}=\frac{1}{n} \sum_{x=i}^{n} y_{i}, \\
b_{i}=\frac{1}{n} \sum_{i=1}^{n} x_{i} y_{i}, \\
b_{i u}=\frac{1}{n} \sum_{i=1}^{n} x_{i} x_{u} y_{i}, \\
b_{i u k}=\frac{1}{n} \sum_{i=1}^{n} x_{i} x_{u} x_{k} y_{i},
\end{gathered}
$$

where $x_{i}, x_{u}, x_{k}$ - natural values $i, u, k$-factor experiments $y_{i}$ - parameter optimization feedback.

Perform the calculations of approximated value of critical cutting depth:

$$
\begin{aligned}
& h_{k \mathrm{p}}=b_{0}+\frac{b_{i}}{\Delta X_{i}}\left(X_{i}-X_{i 0}\right)+ \\
& +\frac{b_{i u}}{\Delta X_{i} \Delta X_{u}}\left(X_{i}-X_{i 0}\right)\left(X_{u}-X_{u 0}\right)+ \\
& +\frac{b_{i u k}}{\Delta X_{i} \Delta X_{u} \Delta X_{k}}\left(X_{i}-X_{i 0}\right) \times \\
& \times\left(X_{u}-X_{u 0}\right)\left(X_{k}-X_{k 0}\right)
\end{aligned}
$$

\begin{tabular}{|c|c|c|c|c|c|c|c|c|c|c|c|c|c|c|c|c|c|}
\hline \multirow{4}{*}{ Factor } & \multirow{2}{*}{\multicolumn{2}{|c|}{ Marking }} & \multirow{4}{*}{ 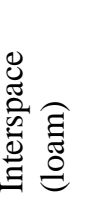 } & \multirow{4}{*}{ 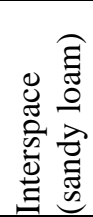 } & \multirow{4}{*}{ 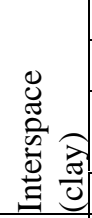 } & \multicolumn{12}{|c|}{ Level of variation } \\
\hline & & & & & & & & & & Natura & & & & & \multirow{2}{*}{\multicolumn{3}{|c|}{ Code }} \\
\hline & \multirow{2}{*}{$\begin{array}{l}\bar{T} \\
\text { 吾 } \\
\text { Z }\end{array}$} & \multirow{2}{*}{$\frac{8}{0}$} & & & & \multicolumn{3}{|c|}{ Semisolid loam } & \multicolumn{3}{|c|}{ Solid sandy loam } & \multicolumn{3}{|c|}{ Hardplastic clay } & & & \\
\hline & & & & & & top & mid. & bot. & top & mid. & bot. & top & mid. & bot. & top & \begin{tabular}{|l|} 
mid. \\
\end{tabular} & bot. \\
\hline $\begin{array}{c}\text { Blade } \\
\text { width, } b, \mathrm{~m}\end{array}$ & $X_{1}$ & $x_{1}$ & 0,1 & 0,1 & 0,1 & 0,25 & 0,15 & 0,05 & 0,25 & 0,15 & 0,05 & 0,25 & 0,15 & 0,05 & 1 & 0 & -1 \\
\hline $\begin{array}{c}\text { Knife`s } \\
\text { cutting } \\
\text { angle, } \alpha, \text { rad }\end{array}$ & $X_{2}$ & $x_{2}$ & 0,349 & 0,349 & 0,349 & 1,047 & 0,698 & 0,349 & 1,047 & 0,698 & 0,349 & 1,047 & 0,698 & 0,349 & 1 & 0 & -1 \\
\hline $\begin{array}{c}\text { Cutting } \\
\text { speed, } \\
V, \mathrm{~m} / \mathrm{s}\end{array}$ & $X_{3}$ & $x_{3}$ & 2,09 & 1,725 & 2,275 & 5,18 & 3,09 & 1 & 4,45 & 2,725 & 1 & 5,55 & 3,275 & 1 & 1 & 0 & -1 \\
\hline
\end{tabular}

When substituting numerical values of the components of the equation (8) for different soil types, we obtain the following expression:

Table 2. Value factors and levels of variation for different types of soil 
Table 3. Matrix of 3-factor`s planning

\begin{tabular}{|c|c|c|c|c|c|c|c|c|c|c|c|}
\hline № & $x_{0}$ & $x_{1}$ & $x_{2}$ & $x_{3}$ & $x_{1} x_{2}$ & $x_{1} x_{3}$ & $x_{2} x_{3}$ & $x_{1} x_{2} x_{3}$ & $\begin{array}{c}y_{\mathrm{i}} \\
\text { Semisolid loam }\end{array}$ & $\begin{array}{c}y_{\mathrm{i}} \\
\text { Solid sandy } \\
\text { loam }\end{array}$ & $\begin{array}{c}y_{\mathrm{i}} \\
\text { Hardplastic } \\
\text { clay }\end{array}$ \\
\hline 1 & + & -1 & -1 & -1 & 1 & 1 & 1 & -1 & 0,516 & 0,707 & 0,54 \\
\hline 2 & + & 1 & -1 & -1 & -1 & -1 & 1 & 1 & 2,581 & 3,533 & 2,702 \\
\hline 3 & + & -1 & 1 & -1 & -1 & 1 & -1 & 1 & 0,274 & 0,347 & 0,257 \\
\hline 4 & + & 1 & 1 & -1 & 1 & -1 & -1 & -1 & 1,369 & 1,737 & 1,285 \\
\hline 5 & + & -1 & -1 & 1 & 1 & 1 & -1 & 1 & 0,812 & 1,15 & 0,773 \\
\hline 6 & + & 1 & -1 & 1 & -1 & -1 & -1 & -1 & 4,061 & 5,748 & 3,864 \\
\hline 7 & + & -1 & 1 & 1 & -1 & 1 & 1 & -1 & 0,785 & 1,11 & 0,882 \\
\hline 8 & + & 1 & 1 & 1 & 1 & -1 & 1 & 1 & 3,925 & 5,548 & 4,411 \\
\hline \multicolumn{8}{|c|}{ Average value of feedback $y_{i}$} \\
\hline \multicolumn{8}{|c|}{}
\end{tabular}

(for semisolid loam):

$$
\begin{aligned}
& h_{\mathrm{kp}}=1,79+11,91(b-0,15)-0,5788 \div \\
& \times\left(\alpha_{\mathrm{p}}-0,689\right)+0,2894(v-3,09)- \\
& -3,8682(b-0,15)\left(\alpha_{\mathrm{p}}-0,689\right)+ \\
& +1,933(b-0,15)(v-3,09)+0,2207 \times \\
& \times\left(\alpha_{\mathrm{p}}-0,689\right)(v-3,09)+ \\
& +1,4806(b-0,15)\left(\alpha_{\mathrm{p}}-0,689\right)(v-3,09) ;
\end{aligned}
$$

(for solid sandy loam):

$$
\begin{aligned}
& h_{\mathrm{kp}}=2,485+16,57(b-0,15)-0,8596 \times \\
& \times\left(\alpha_{\mathrm{p}}-0,689\right)+0,524(v-2,725)- \\
& -5,7304(b-0,15)\left(\alpha_{\mathrm{p}}-0,689\right)+ \\
& +3,4956(b-0,15)(v-2,725)+0,3986 \times \\
& \times\left(\alpha_{\mathrm{p}}-0,689\right)(v-2,725)+2,6577 \times \\
& \times(b-0,15)\left(\alpha_{\mathrm{p}}-0,689\right)(v-2,725)
\end{aligned}
$$

(for hardplastic clay):

$$
\begin{aligned}
& h_{\mathrm{kp}}=1,839+12,26(b-0,15)-0,3752 \times \\
& \times\left(\alpha_{\mathrm{p}}-0,689\right)+0,2826(v-3,275)- \\
& -2,4928(b-0,15)\left(\alpha_{\mathrm{p}}-0,689\right)+ \\
& +1,8857(b-0,15)(v-3,275)+0,3715 \times \\
& \times\left(\alpha_{\mathrm{p}}-0,689\right)(v-3,275)+2,4811 \times \\
& \times(b-0,15)\left(\alpha_{\mathrm{p}}-0,689\right)(v-3,275)
\end{aligned}
$$

Puts the obtained coefficients of equations, theoretical and approximated value of critical cutting depth in Table 4 and 5.
Table 4. The coefficients of the regression equation $b_{i}$ and approximated value of combined cutting critical depths

\begin{tabular}{|l|l|l|l|}
\hline & Loam & $\begin{array}{l}\text { Sandy } \\
\text { loam }\end{array}$ & Clay \\
\hline$b_{0}$ & 1,790 & 2,485 & 1,839 \\
\hline$b_{1}$ & 1,194 & 1,657 & 1,226 \\
\hline$b_{2}$ & $-0,202$ & $-0,300$ & $-0,131$ \\
\hline$b_{3}$ & 0,605 & 0,904 & 0,643 \\
\hline$b_{12}$ & $-0,135$ & $-0,200$ & $-0,087$ \\
\hline$b_{13}$ & 0,404 & 0,603 & 0,429 \\
\hline$b_{23}$ & 0,161 & 0,240 & 0,295 \\
\hline$b_{123}$ & 0,108 & 0,160 & 0,197 \\
\hline
\end{tabular}

Carry the appreciation of the regression coefficients and adequacy test of regression equations using dispersion analysis.

Determine the degree of deviation values $u$ - research of a random variable from its average value:

$$
S_{u}^{2}=\sum_{i=1}^{n}\left(y_{i}-\bar{y}\right)^{2}
$$

where $\bar{y}-$ average value of the research.

Dispersion of the research:

$$
S_{y}^{2}=\frac{S_{u}^{2}}{N}
$$

where $N$ - numbers of researches.

The statistical significance of the regression coefficients is checked using $t-$ Student's criterion [14 - 17]:

$$
t_{b i}=\frac{\left|b_{i}\right|}{S_{b i}}
$$


Table 5. Plan $2^{3}$ and the results of calculations

\begin{tabular}{|c|c|c|c|c|c|c|c|c|c|c|c|c|c|c|}
\hline \multirow[t]{2}{*}{ № } & \multirow{2}{*}{$\begin{array}{l}\Xi \\
\frac{E}{0} \\
. \frac{0}{3} \\
\frac{0}{0} \\
\frac{\pi}{n}\end{array}$} & \multirow{2}{*}{$\begin{array}{l}\vec{Z} \\
\stackrel{\Xi}{0} \\
000 \\
\Xi \\
00 \\
\Xi \\
\Xi \\
\Xi\end{array}$} & \multicolumn{3}{|c|}{ 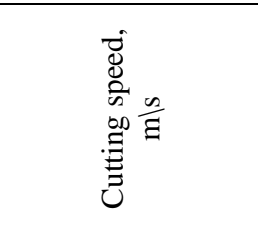 } & 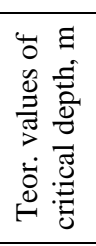 & 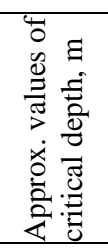 & 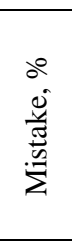 & 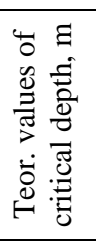 & 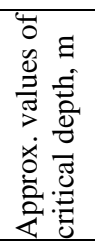 & 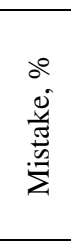 & 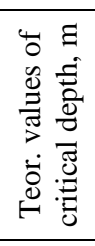 & 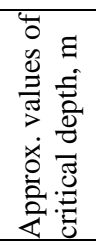 & 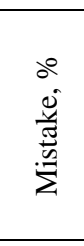 \\
\hline & & & 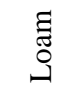 & 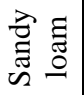 & $\vec{\Xi}$ & \multicolumn{3}{|c|}{ Loam } & \multicolumn{3}{|c|}{ Sandy loam } & \multicolumn{3}{|c|}{ Clay } \\
\hline 1 & 0,05 & 0,349 & 1,0 & 1,0 & 1,0 & 0,516 & 0,5156 & 0,03 & 0,707 & 0,707 & 0,3 & 0,54 & 0,54 & 0,04 \\
\hline 2 & 0,25 & 0,349 & 1,0 & 1,0 & 1,0 & 2,581 & 2,5806 & 0,03 & 3,533 & 3,533 & 0,8 & 2,702 & 2,702 & 0,04 \\
\hline 3 & 0,05 & 1,047 & 1,0 & 1,0 & 1,0 & 0,274 & 0,2736 & 0,03 & 0,347 & 0,347 & 0,55 & 0,257 & 0,257 & 0,011 \\
\hline 4 & 0,25 & 1,047 & 1,0 & 1,0 & 1,0 & 1,369 & 1,3686 & 0,03 & 1,737 & 1,737 & 0,44 & 1,285 & 1,285 & 0,04 \\
\hline 5 & 0,05 & 0,349 & 5,18 & 4,45 & 5,55 & 0,812 & 0,8116 & 0,03 & 1,15 & 1,15 & 0,88 & 0,773 & 0,773 & 0,011 \\
\hline 6 & 0,25 & 0,349 & 5,18 & 4,45 & 5,55 & 4,061 & 4,0606 & 0,03 & 5,748 & 5,748 & 0,88 & 3,864 & 3,864 & 0,044 \\
\hline 7 & 0,05 & 1,047 & 5,18 & 4,45 & 5,55 & 0,785 & 0,7846 & 0,03 & 1,11 & 1,11 & 0,66 & 0,882 & 0,882 & 0,011 \\
\hline 8 & 0,25 & 1,047 & 5,18 & 4,45 & 5,55 & 3,925 & 3,9246 & 0,03 & 5,548 & 5,548 & 0 & 4,411 & 4,411 & 0 \\
\hline
\end{tabular}

$$
S_{b i}^{2}=\frac{S_{y}^{2}}{N},
$$

Defined by the formula (11) value $t_{b i}$ is compared with tabulated values $t_{m}$ [13,
Tab.3.2.]. When $t_{b i}>t_{m}$, the coefficient of the regression equation is significant. Otherwise, this ratio should be excluded from the equation.

Table 6. Research dispersion, the statistical significance of the regression coefficients, quadratic error of regression coefficients

\begin{tabular}{|c|c|c|c|c|c|c|c|c|c|c|c|c|}
\hline & \multicolumn{4}{|c|}{ Semisolid loam } & \multicolumn{4}{|c|}{ Solid sandy loam } & \multicolumn{4}{|c|}{ Hardplastic clay } \\
\hline № & $S_{u}^{2}$ & $S_{y}^{2}$ & $S_{b i}$ & $t_{b i}$ & $S_{u}^{2}$ & $S_{y}^{2}$ & $S_{b i}$ & $t_{b i}$ & $S_{u}^{2}$ & $S_{y}^{2}$ & $S_{b i}$ & $t_{b i}$ \\
\hline 1 & 1,623 & \multirow{8}{*}{2,051} & \multirow{8}{*}{0,506} & 3,535 & 3,161 & \multirow{8}{*}{4,137} & \multirow{8}{*}{0,719} & 3,456 & 1,688 & \multirow{8}{*}{2,251} & \multirow{8}{*}{0,530} & 3,467 \\
\hline 2 & 0,626 & & & 2,357 & 1,098 & & & 2,304 & 0,744 & & & 2,312 \\
\hline 3 & 2,298 & & & 0,399 & 4,571 & & & 0,417 & 2,504 & & & 0,246 \\
\hline 4 & 0,177 & & & 1,196 & 0,560 & & & 1,257 & 0,307 & & & 1,213 \\
\hline 5 & 0,956 & & & 0,266 & 1,782 & & & 0,277 & 1,137 & & & 0,164 \\
\hline 6 & 5,157 & & & 0,797 & 10,647 & & & 0,838 & 4,100 & & & 0,808 \\
\hline 7 & 1,010 & & & 0,319 & 1,891 & & & 0,333 & 0,916 & & & 0,555 \\
\hline 8 & 4,558 & & & 0,213 & 9,382 & & & 0,222 & 6,614 & & & 0,370 \\
\hline
\end{tabular}
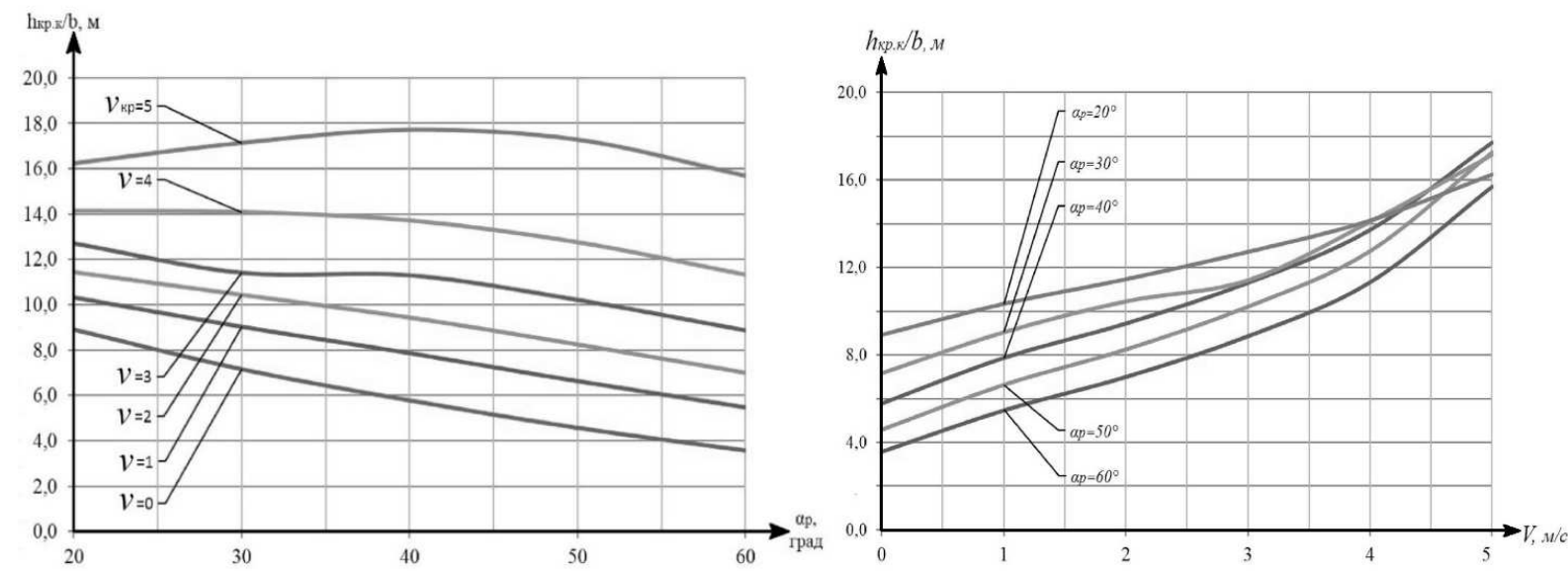

Fig.2. Dependence of the approximated relative critical depth combined cutting soil $h_{\text {кр.к. }}$ from the speed by changing the angle of cutting for semisolid loam 

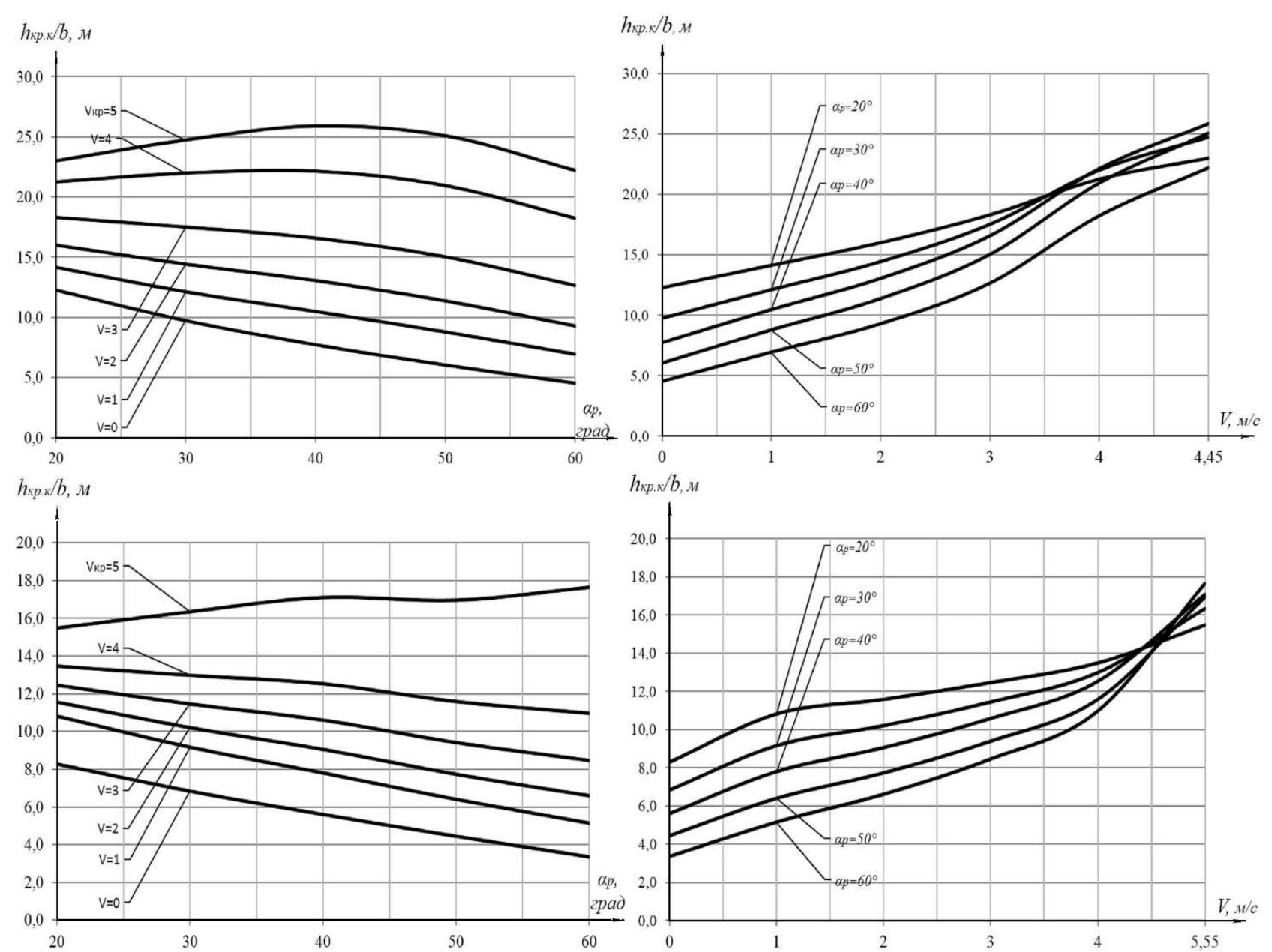

Fig.3. Dependence of the approximated relative critical depth combined cutting soil $h_{\text {кр.к. }}$ from the speed by changing the angle of cutting and dependence of approximated relative critical depth combined cutting soil $h_{\text {кр.к. }}$ from the angle when changing cutting speed, solid sandy loam and hardplastic clay

The value of the research dispersion, statistical significance of regression coefficients and quadratic error of the regression coefficients are entered in Table 6. Dependence of the approximated relative critical depth com-

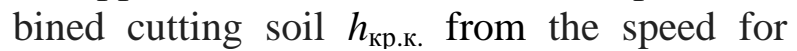
different types of soil are shown on Fig. 2 and Fig. 3.

\section{CONCLUSIONS}

1. The possibility of regression analysis applying of analytical model to approximate the critical depths of combined cutting soil has been shown.

2. Critical depth of combined cutting soil is approximated by the equation with a combination of factors like (8..15), approximation error is less than $1 \%$.
3. Under the calculation dependence, increasing operating speed of $0 \mathrm{~m} / \mathrm{s}$ to $4 \mathrm{~m} / \mathrm{s}$ approximated value of relative critical depth of combined cutting $h_{\text {кр.к. }}$ increases from 3,58 to 14,13 meters for semi-loam; from 4,53 to 22,15 for solid sandy loam; from 3,33 to 13,47 for hardplastic clay depending on the cutting angle.

\section{REFERENCES}

1. Baladynskyi V.L., 1988. Performance and durability of earthmoving reclamation machines. Baladynskyi V.L., Puzychev Iu.V., Smyrnov V.N., Kyslenko A.A. Kiev, Urozhai, 152 (in Russian).

2. Hryshyn V.K., 1975. Statistical methods for the analysis and planning of experiments. Moscow, Publishing MNU, 128 (in Russian). 
3. Haiko G., Zakharchenko P., 2016. Perspectives of tunnel passages construction under the Dnieper. Kiev, Underwater technologies, 7279.

4. Kravets S.V., Zoria R.V., 2015. Effect of speed on the critical depth of cut. Herald NUWEE, Rivne, Technical science, Vol.72(4), 92103. - (in Ukrainian).

5. Kravets S.V., Stinio O.V., 2013. Determination of the critical depth of cut in the combined tiered destruction of soil. Herald Building. Materials Science. Mechanical engineering. Series: Hoisting-and-lifting transport, construction and road machinery and equipment. Vol 72, 128-137. - (in Ukrainian).

6. Kravets S.V., Stinio O.V., 2016. Determination of blocked cutting energy intensity factor and loosening the soil. Scientific Journal NGU, Vol.3, 24-28 (in Ukrainian).

7. Kravets S.V., Kovanko V.V., Luk'ianchuk O.P., 2015. Scientific basis of creating earthtiered machines and underground-moving devices. Monograph, NUWEE, 24-48 (in Ukrainian).

8. Kravets S.V. Romanovskyi O.L., Kyrykovych V.D., Muzychuk I.M., 2006. Effect of hydrostatic pressure on critical depth of the combined tiered cutting soil Herald Visnuk NUWEE, Vol.2(34), Part 2, Rivne, 23-243 (in Ukrainian).

9. Kravets S.V., 1999. Soil-protection and energy-saving machines for laying underground utilities. (Basic theory, design and creation). Rivne, RDTU, 37-52. - (in Ukrainian).

10.Lvovskyi E.N., 1988. Statistical methods for constructing empirical formulas. Moscow, High school, 148-149. - (in Russian).

11.Vasylenko P.M., Pohorelyi L.V., 1985. Fundamentals of Scientific Research. Kiev, High school, 164-166. - (in Russian).

12.Vetrov Yu.A., 1971. Soil cutting with digging machines. Moscow, Mashynostroenye, 136. (in Russian).

13.Venykov V.A., Venykov V.H., 1984. Theory of similarity and modeling. Moscow, High school, 248-251. - (in Russian).

14.Voronov V.H., Ehorov A.E., Azarov H.N., Koval A.V., 1986. Investigation of devices and automation systems by the method of experiment planning. Kharkiv, High school, 131. (in Russian).

15.Rebrova I.A., 2010. Experiment planning, tutorial. Omsk, SibADI, 76-89. - (in Russian).
16.Rydakov G.M., 2004. Basics of planning a research experiment. Tashkent, Ukityvchi, 3334. - (in Russian).

17.Rohov V.A., Pozdniak H.H., 2005. Technique and practice of technical experiments: study allowance of high ed. Moscow, Publishing house Academy, 103-105. - (in Russian).

18. Komarov M.S., 1982. Fundamentals of Scientific Research. Lvov, High school, 38-46. - (in Russian).

19.Sydenko V.M., Hrushko Y.M., 1979. Fundamentals of Scientific Research. Kharkiv, High school, 131-132.

20.Sukharev E.A., 1989. Methods of scientific research of construction and meliorative technic, Tutorial. Kiev, UMK HE, 68-79. - (in Russian).

21.Stanevskyi V.P., 1984. Perfection of the working process of digging. Kiev, High school, KGU, 36-64. - (in Russian).

22.Sukach M.K., Lysak S., 2017. Kinematics parameters of twosectional trencher's. Kiev, Underwater technologies, 16-22.

\section{Аппроксимация математической модели критической глубины комбинированного резания грунтов на основе регрессионного анализа}

\section{Святослав Кравеи, Роман Зоря}

Аннотация. Представлены результаты аппроксимации математической модели процессов резания и рыхления почвы для получения аналитической зависимости определения критической глубины разрыхления с учетом скорости рабочего органа при комбинированном поярусном разрушении почвы. Проведено аппроксимацию на основе регрессионного анализа, используемую при обработке данных, полученных в результате экспериментов с определенным количеством параллельных наблюдений в опыте. Построены графики зависимости между аппроксимированной относительной критической глубиной, рабочей скоростью рабочего органа и углом резки почвы. Определены значения критической глубины разрыхления для пяти типов грунта и полного диапазона рабочих скоростей, в зависимости от физико-механических свойств почвы.

Ключевые слова: угол резания, глубина разрыхления, рабочая скорость, критическая глубина, комбинированная резка, уравнение регрессии, дисперсия исследования. 